\title{
Comparison of Single and Group Jet Grouting Columns Capacity Based on Field Load Test and Theoretical Methods
}

\author{
Ali M. Al-Kinani ${ }^{\text {a*}}$, Mahmood D. Ahmed ${ }^{\mathrm{b}}$ \\ ${ }^{a}$ PhD Student, Department of Civil Engineering, University of Baghdad, Baghdad, Iraq. \\ ${ }^{b}$ Associate Professor, Department of Civil Engineering, University of Baghdad, Baghdad, Iraq. \\ Received 17 February 2019; Accepted 08 May 2019
}

\begin{abstract}
The evaluation of axial capacity of jet grouted soil cement columns in soft soil is a complicated issue because it depends according to the number of factors such as, soil type, influence mixture between soil and grouting materials, nozzle jet energy, jet grouting and water flow rate, rotation and lifting speed. These parameters related to the type of jet grouting methods (single, double and triple system). Most methods of design the bearing capacity of the jet-grouting column based on experience. Therefore, some designer calculates the bearing capacity of the jet grouting column based on jet grout section capacity. In this paper, different theoretical methods have been used to estimate of the jet grouting soil-cement capacity, such as Poulos and Davis, 1980 methods and then their comparison with the pile load test calculations based on the quick pile load test as presented in ASTM-D1143-07. Therefore, the study describes a prototype test single and group jet grout soil-cement models of arrangement $(1 \times 1,1 \times 2$ and $2 \times 2)$ for total length to diameter ratios $(\mathrm{L} / \mathrm{D})$ is 13.33 and clear spacing three times of diameter has been constructed in soft clayey soils in the right bank of the Euphrates River, at AlNasiriyah city. As a result, the theoretical method for estimation the bearing capacity gives unfaithful values for the single and group jet grout column compared to the load- settlement calculations obtained from field pile load test data. On the other hand, the Hansen's 90\% and Butler and Hoy's given closer results to each other and may be considered faithful interpretation methods to compute the bearing capacity of single and group jet grouting columns.
\end{abstract}

Keywords: Jet Grouting Columns; Field Load Test; Axial Capacity; Soft Soil.

\section{Introduction}

Jet under high pressure is widely used in the industry, while in constructions of civil engineering are most significantly, to cut soil structures in-situ the high velocity of jetting material are used for ground improvement [1]. Jet grouting is a soil treatment technique adoption a high hydraulic energy to destroy the surrounding soil. Ground improvement by Jet grouting technology can be used in varied and difficult geological and geotechnical situations, showing its practical and economic advantages, in addition to the importance of the performance control on site, before and during the construction of the final foundations [2].

When soil particles were excavated then spoil outside the hole and recouped with cementing materials such as Portland cement to create a soil cement column aspect (soilcrete) [3] Construction of spoil, which could then again be recycled or integrated on the ground works [4]. When designing jet injection columns, change in the length of the jet grout columns and soil conditions must be carefully and correctly defined [5]. Jet grouting has increasing uses in the last

* Corresponding author: ali1984kinani@gmail.com

http://dx.doi.org/10.28991/cej-2019-03091337

(C) 2019 by the authors. Licensee C.E.J, Tehran, Iran. This article is an open access article distributed under the terms and conditions of the Creative Commons Attribution (CC-BY) license (http://creativecommons.org/licenses/by/4.0/). 
years in the ground improvement that effort of low strength, permeability and seepage problems. Jet Grouting has high potential application to decrease settlement in embankments [6]. Soft soil development technologies based on chemical effects, such as deep mixing and jet grouting are usually accepted to improve stability when substructures are constructed in soft sediments. Jet grouting technology has become popular because of its very ease of installation, low cost, low noise and no vibration accrues. So, it's best suitable, especially for the city constructions, noise, vibration and site limitation area is limited [7-9]. Bustamante (2002) according to the back analysis of a large number of results from axial load tests performed on jet grouting soil-cement columns prepared with removable extensometers [10]. According to the interaction between the jet grout column installations of soil-cement reinforcing elements considerably increase the serviceability of the foundation by means of increasing its strain characteristics and active protection of soils from the influence of the seismic vibrations, providing for the safe operation of the sports structure [11]. Malinin, et al. (2010) studied the experimental effect of soil in different condition in getting grouting parameters, the study consists of three series of jet grouting column worked in soils of different cohesion values, at last, the study explains that the jet grout column diameter variation which reach up to $50 \%$ influenced by the type of soil and decrease the time of treatment and increase of monitor rotation speed decrease the column diameter and can the result is a bad soil-cement mixing [12]. Juzwa and Bzówka (2016) showed that the highest settlements of jet grouting columns from the center of the group and if the group is larger (more columns in the group) than the values of settlements are increasing [13]. The jet grouting method is one of the greatest common techniques for strengthening soft soils. Jet grouting columns allow for transmitting substantial loads through the reinforced soft soils and reduce the construction's settlement [13, 14]. The main factors that effect on jet grouting columns geometry are soil characteristic and technical parameters of the jet grouting system such as injection pressure, dimension of nozzles and rotation speed during injection [15].

\section{Research Methodology}

Many different ways are wont to prepare the jet grouting soilcrete and measure their properties. However, those methods are site-conditions and involve several limitations in terms of jet grouting systems, varieties of native soil, and jet grouting parameters. So, the most effective way to measure jet grouting performance and soilcrete properties is by conducting a prototype model experiment simulation of jet grouting in a field with real soil condition and with actual jet grouting parameters and instruments. In spite of, the particular jet grouting equipment's has been just too massive to be used. The choice was created for this project to style and build a machine of jet grouting instrumentality that will have virtually constant ability as actual field instruments however with a reduced size and cost. Therefore, the field work conducted in this study is summarized in the Figure 1.

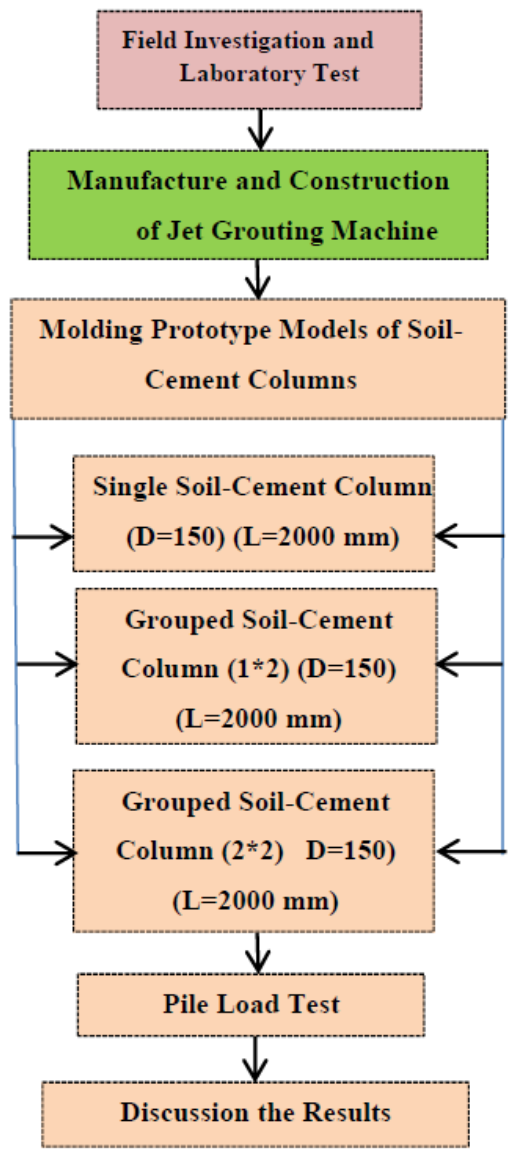

Figure 1. Flow Chart of the Field Program 


\subsection{Field Investigation and Soil Sampling}

The site of the conducted study was located at the distance $100 \mathrm{~m}$ on the right bank of the Euphrates River, in an Al Nasiriyah city $(375 \mathrm{~km}$ southeast of Baghdad see Figure 2. The site investigation included drilling borehole $10 \mathrm{~m}$ in length, carrying out in situ SPT and performing the laboratory testing of the repressive soil samples. The physical properties of the soil and Portland cement are represented in Tables 1 to 5.
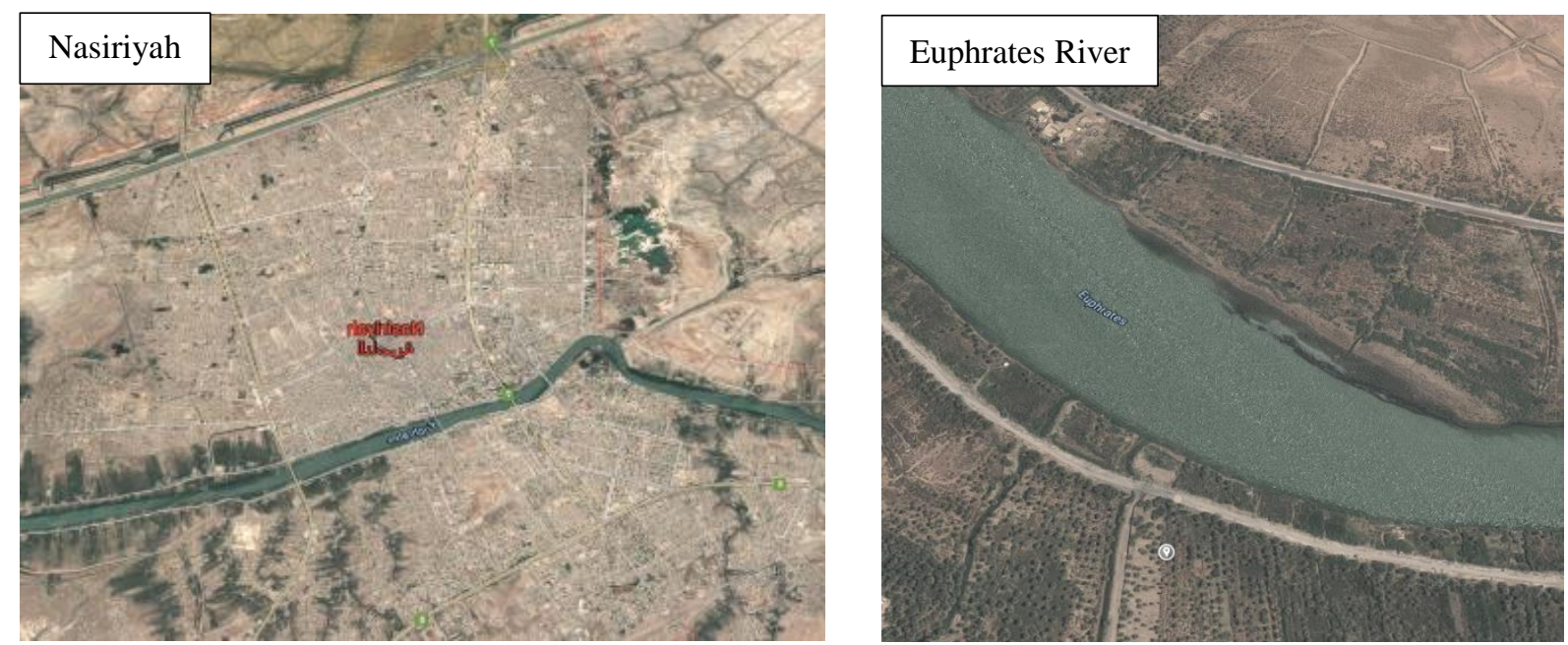

Figure 2. Location of the study area

Table 1. Soil Description and Classification

\begin{tabular}{|c|c|c|c|c|c|c|c|}
\hline \multirow{2}{*}{$\begin{array}{c}\text { Depth } \\
(\mathbf{m})\end{array}$} & \multirow{2}{*}{$\begin{array}{l}\text { Water table (m) } \\
\text { from the top of } B . H\end{array}$} & \multirow{2}{*}{$\begin{array}{c}\gamma_{w e t} \\
\mathbf{k N} / \mathbf{m}^{3}\end{array}$} & \multicolumn{4}{|c|}{ Particle Size Distribution } & \multirow{2}{*}{ USCS } \\
\hline & & & Clay \% & Silt \% & Sand \% & Gravel \% & \\
\hline $0-1$ & \multirow{6}{*}{0.75} & ---- & --- & ---- & ---- & ---- & Fill \\
\hline $1-2.5$ & & 20.48 & 61 & 39 & 0 & 0 & $\mathrm{CL}$ \\
\hline $2.5-3.5$ & & 21.02 & 70 & 30 & 0 & 0 & $\mathrm{CH}$ \\
\hline $3.5-4.5$ & & 21.98 & 72 & 28 & 0 & 0 & $\mathrm{CH}$ \\
\hline $4.5-7.5$ & & 21.5 & 60 & 40 & 0 & 0 & CL \\
\hline $7.5-9.0$ & & 23.4 & 62 & 38 & 0 & 0 & CL \\
\hline
\end{tabular}

Table 2. Results for corrected SPT at the specified depth

\begin{tabular}{cc}
\hline Depth $(\mathbf{m})$ & SPT \\
\hline $0-1.5$ & 0 \\
$1.5-3.0$ & 3 \\
$4.5-6.0$ & 4 \\
$9.0-10$ & 11 \\
\hline
\end{tabular}

Table 3. Soil properties

\begin{tabular}{ccccc}
\hline Depth $(\mathbf{m})$ & L.L \% & P.L \% & P.I\% & G.S \\
\hline $0-1$ & 32 & 15 & 17 & 2.51 \\
$1-2.5$ & 34 & 19 & 15 & 2.62 \\
$2.5-3.5$ & 60 & 29 & 31 & 2.78 \\
$3.5-4.5$ & 59 & 30 & 29 & 2.76 \\
$4.5-7.5$ & 35 & 21 & 14 & 2.58 \\
$7.5-9.0$ & 36 & 21 & 15 & 2.61 \\
\hline
\end{tabular}

Table 4. Results of Undrained Shear Strength

\begin{tabular}{ccc}
\hline Depth (m) & $\mathbf{q}$ unconfined $(\mathbf{k P a})$ & $\mathbf{C u}(\mathbf{k P a})$ \\
\hline $1.0-2.5$ & 73 & 36 \\
$2.5-3.5$ & 42 & 21 \\
$3.5-4.5$ & 76 & 38 \\
$4.5-7.5$ & 86 & 43 \\
\hline
\end{tabular}


Table 5. Chemical and physical properties of Portland cement

\begin{tabular}{lc}
\hline Index property & Index value \\
\hline Compressive strength after 3 days (MPa) & 26 \\
Compressive strength after 7 days (MPa) & 33 \\
Time of initial setting (hour) & 2.17 \\
Time of final setting (hour) & 4.156 \\
$\mathrm{SiO}_{2}(\%)$ & 19.54 \\
$\mathrm{CaO}(\%)$ & 64.32 \\
$\mathrm{Al}_{2} \mathrm{O}_{3}(\%)$ & 4.13 \\
$\mathrm{Fe}_{2} \mathrm{O}_{3}(\%)$ & 4.97 \\
$\mathrm{MgO} \%)$ & 2.39 \\
$\mathrm{SO}_{3}(\%)$ & 2.42 \\
$\mathrm{C}_{3} \mathrm{~A}(\%)$ & 2.49 \\
$\mathrm{LOI}(\%)$ & 1.01 \\
$\mathrm{Salts}$ insoluble (\%) & 1.23 \\
Losses in heating (\%) & 3.23 \\
Fineness of Cement (Blaine s Sp. Surface) $\left(\mathrm{m}^{2} / \mathrm{kg}\right)$ & 372 \\
\hline
\end{tabular}

\subsection{Jet Grouting Field Design}

To implement jet grouting technique, it is necessary to design and manufacture an actual jet grouting system to simulate the actual process to great soilcrete column. The main equipment of the system includes:

- Jetting Grouting Machine.

- High Pressure Water Pump.

- High Pressure Grout Pump.

- Mixer Grout Unit.

- Nozzles.

\subsubsection{Jetting Machine}

This machine design and manufacture using iron frame and consist of many apparatus to construct a jet grout column as shown in Figure 3. The main parts of the machine consist of a string jet grouting drill rod (solid iron tube monitor) with the outer diameter is $50(\mathrm{~mm})$ and the inner diameter is $30(\mathrm{~mm})$. The upper part of it is fitted with stainless steel swivel to provide that during rotation water or grouting material can be passed through the drill string to the nozzle, and the lower part is fitted with the nozzle and drill bit. The maximum vertical motion is $(0.5 \mathrm{~cm} / \mathrm{sec})$. The mechanism of rotary unites consist of the fitting the drill rod with 0.25 (horse power) gearbox motor with maximum velocity 20 (rpm).

\subsubsection{High pressure water pump}

The selection of the sort of water should be supporting the sort of application and quantity of energy required. The water pump rate is $(11 \mathrm{~L} / \mathrm{min})$ with maximum pressure $(200 \mathrm{bar})$ at a maximum speed of $1600 \mathrm{rpm}$. The water of the pump was connected with to iron storage tank with a capability of $(1000 \mathrm{~L})$ using strengthened rubber house with a $(1 / 5$ inch) diameter as shown in Figure 4.

\subsubsection{High Pressure Grouting Pump}

Grout pumps and apportionment systems should be chosen for reasonable injection rates in order to prevent the development of excessive pressures during injection. A progressive cavity pump is therefore ideal for liquids with higher viscosities. In the field work the grout pumps chose was a progressive cavity pump with rated capacity $\left(5.0 \mathrm{~m}^{3} / \mathrm{hr}\right.$.), a rated differential pressure $(3.0 \mathrm{bar})$, rated speed $(1450 \mathrm{rpm})$ and maximum allowable casing pressure (10 bar) as shown in Figure 5. 


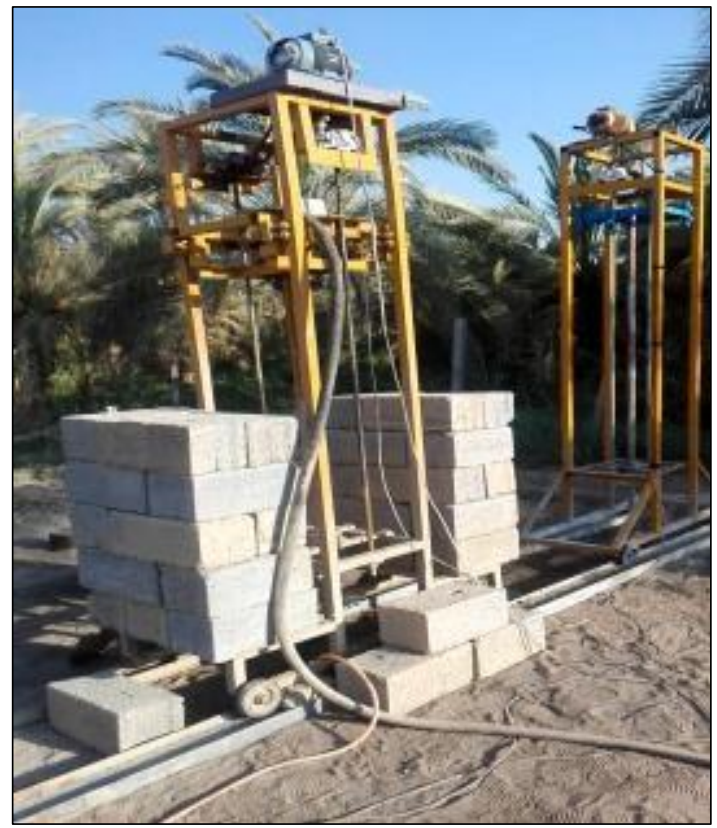

Figure 3. Jet grouting machine

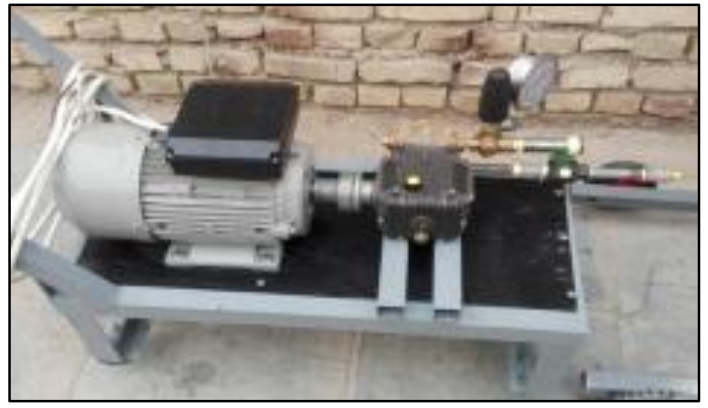

Figure 4. High pressure water jet pump

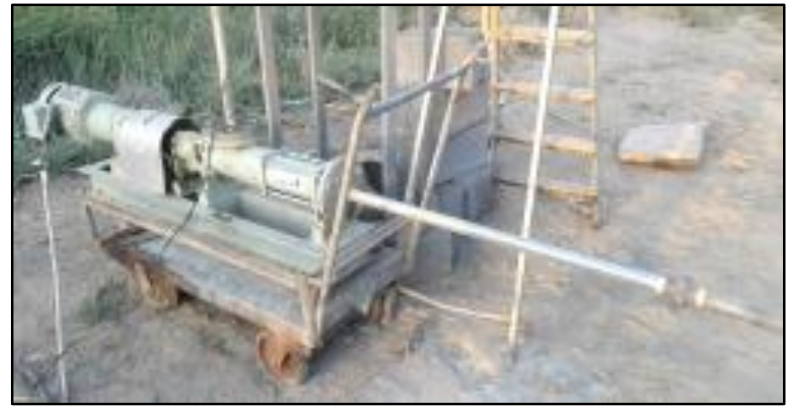

Figure 5. High pressure jet grouting pump

\subsubsection{Mixer Unit}

The cylindrical mixer is made from an iron with $800(\mathrm{~mm})$ in heights and $500(\mathrm{~mm})$ in diameters. The Cement grout paddle blenders are fitted with a vertical shaft and with uncommonly planned cutting edges and confounds to build up a high shear blending activity, safeguarding a fast and careful blend.

\subsubsection{Nozzle}

The smallest and the most important part of the jetting system are nozzles. It is very effective to control the pressure distribution and pattern of the jetting. According that, in the field work the Electroformed Nickel nozzles was the best choose from water jetting Brass nozzle with the diameter 2 and $3 \mathrm{~mm}$ in grout jetting. The maximum flow rate is $\left(\mathrm{Q}_{\text {water }}=13.9 \mathrm{~L} / \mathrm{min}\right)$ and the maximum water pressure $(200 \mathrm{bar})$.

\section{Material and Methods}

The jet grouting construction program consists of seven jet grout column classified in groups as shown in Figure 1 . Many limits influenced the depth and diameter of a soil cement column such as jetting pressure, rode rotation, rod vertical motion and the length to width ratio (L/d) etc. The Jet grout column diameter was $150 \mathrm{~mm}$, and the total length was $2000 \mathrm{~mm}$ and the $(\mathrm{L} / \mathrm{d})$ ratio was 13.3 for the single and group columns with centre to centre clear distance (S=3D). The construction theory of jet grouting was double fluid system (water, grout, and zero air pressure to reduce the diameter of the column) can be represented as:

- The water jet was at first used to create borehole to the required depth under pressure 75 bar. The drilling tools generally rotated at a continuous rate $30 \mathrm{rpm}$ to erode the soil and create column geometry.

- Therefore, after the erosion process has done, the high pressure of grout slurry (Portland cement and water) was 6 bar with water cement ratio (1:1) injected into the hole. 
- In general, the setting time of the hardening slurry and soil mixture was $24 \mathrm{hr}$. On the other hand, the total time of the process to complete the drill the borehole by water jetting and slurry injection to build up the soilcrete was $2 \mathrm{hr}$.

- As the result, the shape of soilcrete column was absolutely regular and looked as the cylinder and the cross sectional diameter of the column was measured at the top $(0.5-0.6 \mathrm{~m})$ from the column head. The all construction works of group are represented in Figure 6, Figure 7 and Figure 8 respectively.
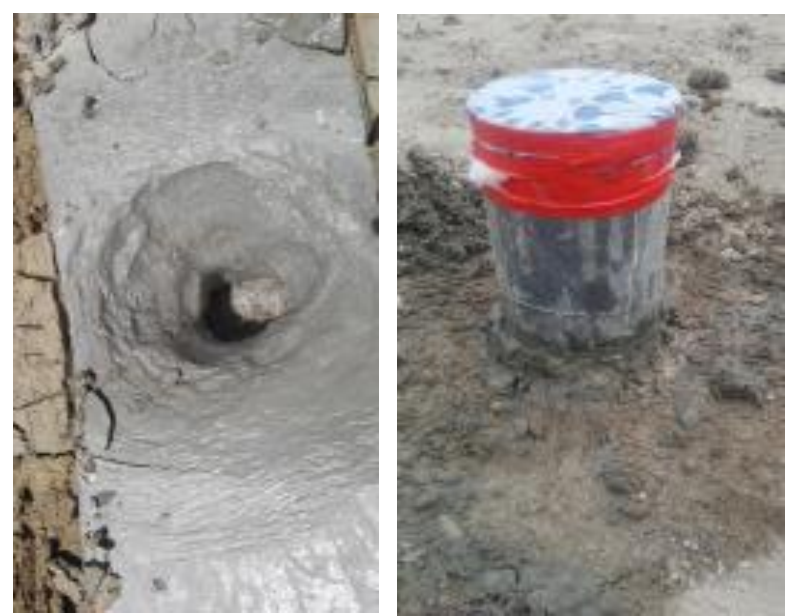

Figure 6. Construction steps of single jet grout soil-cement column $(D=150 \mathrm{~mm}$ and $\mathrm{L}=2000 \mathrm{~mm})$
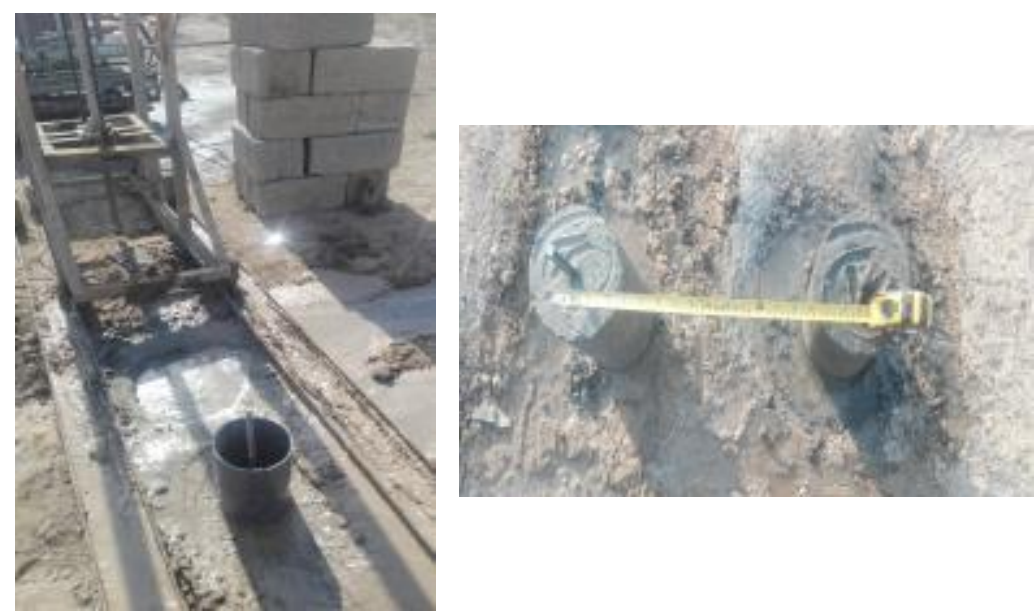

Figure 7. Construction steps of group jet grout soil-cement column $(1 \times 2),(\mathrm{S}=3 \mathrm{D})$

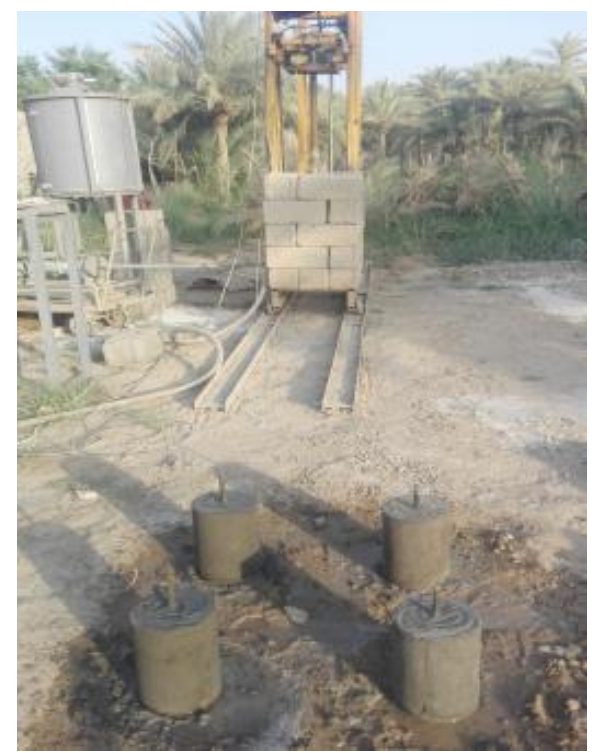

Figure 8. Construction steps of group jet grout soil-cement column $(2 \times 2),(\mathrm{S}=3 \mathrm{D})$ 


\subsection{Construction of Concrete Cap for Jet Grouted Column}

A reinforced concrete cap was required for transferring the loading forces from the assembly (Structure of kantledge blocks) to the soil cement column during the pile load test. A concrete cap was chosen for one of the jet-grouted column and a reinforcement cap cast-in place for the other. Figures 9 and 10 depict the schematic of reinforcement concrete cap head connection. The dimensions of cap and steel reinforcement for concrete cap was calculated according to meet standard code requirements (ACI 318-14) [16]. The formwork fabricated for casting the concrete cap is displayed in Figure 11.
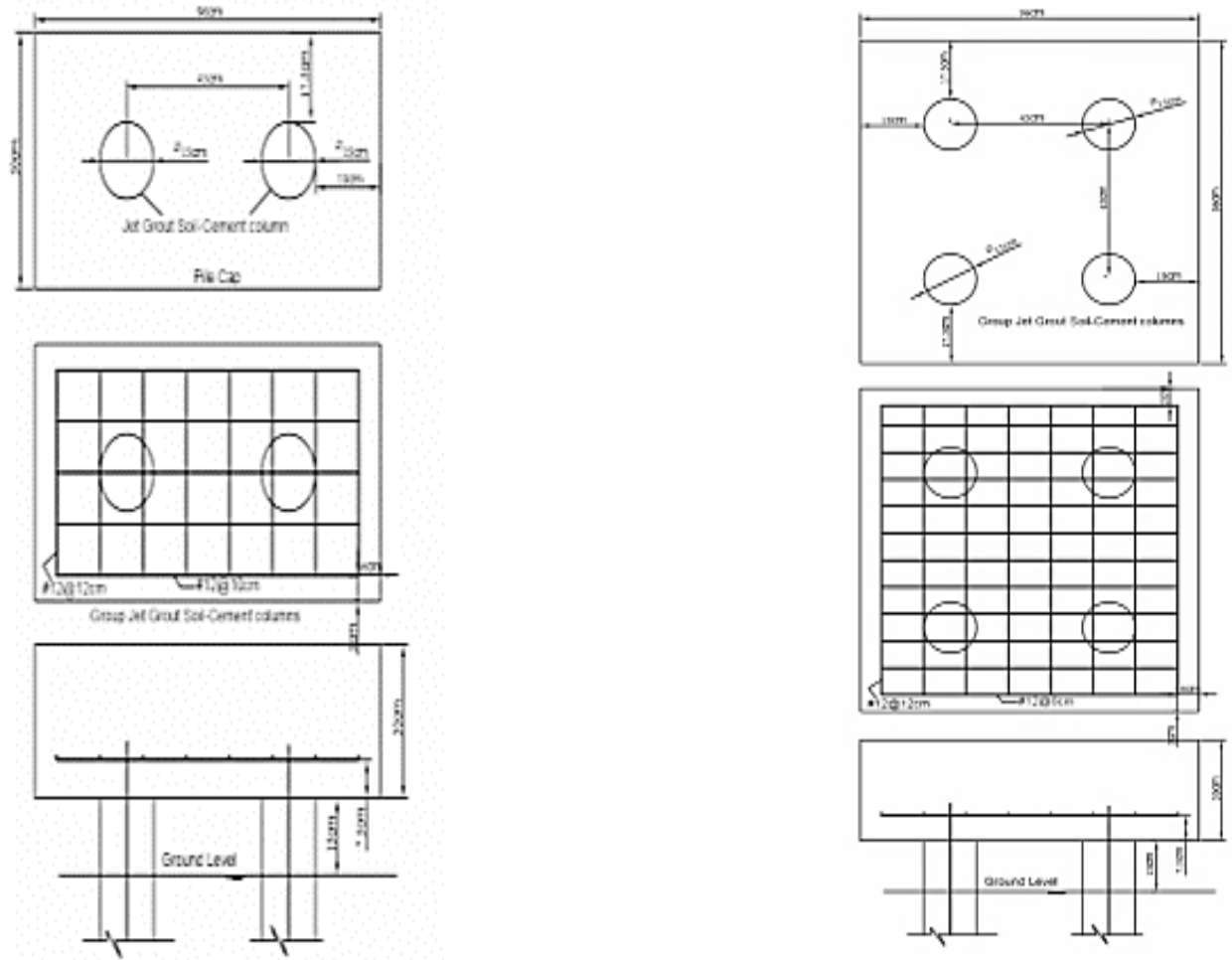

Figure 9. Schematic represented pile cap of jet grout soilcement column group $(1 \times 2)$

Figure 10. Schematic represented pile cap of jet grout soilcement column group $(2 \times 2)$
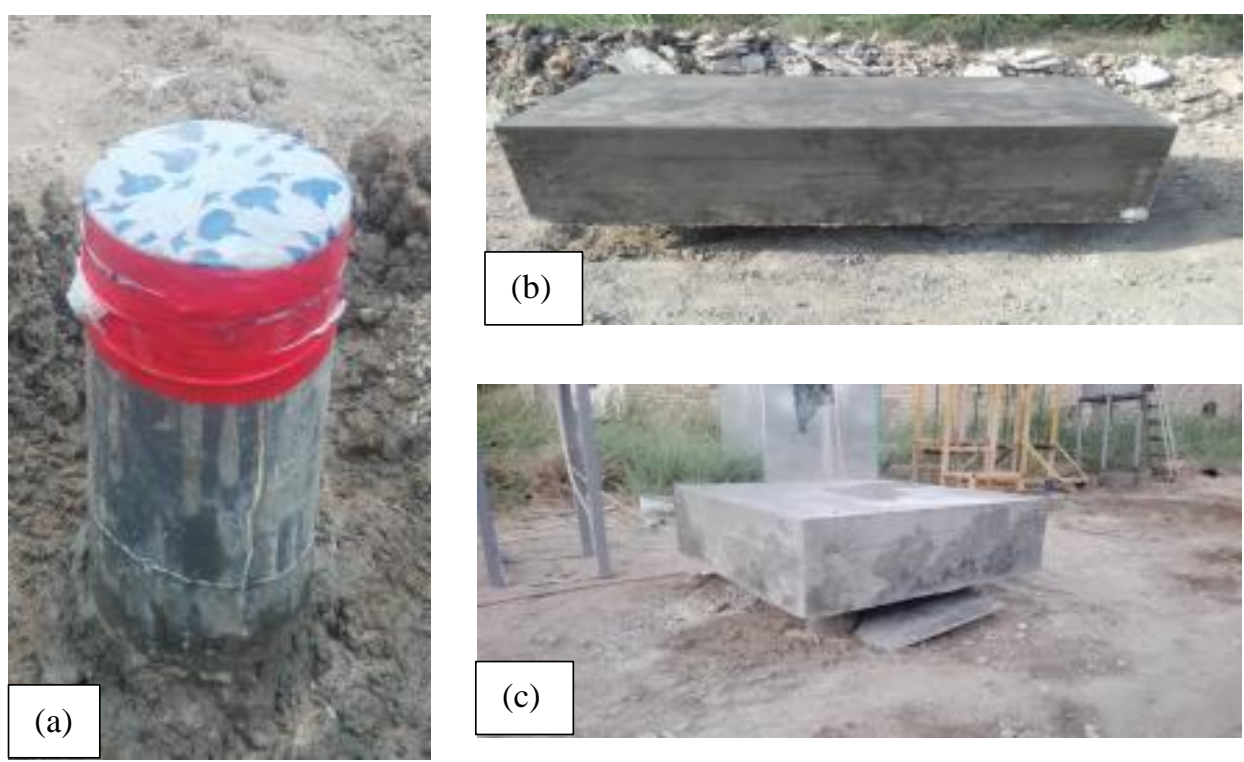

Figure 11. Cast in place pile cap of soil-cement column; (a) Single; (b) Group $(1 \times 2)$; (c) Group $(2 \times 2)$ 


\subsection{Pile Load Test}

The two important aspects considered in the design of jet grout soil-cement columns are the load carrying capacity and expected settlements due to applied axial loads. The jet grout capacity can be evaluated using a theoretical approach based on Poulos and Davis (1980) [17]. Generally, these methods tend to estimate jet grout column capacities with variable degrees of accuracy. The most accurate approach to evaluation of the jet capacity is to perform full-scale load tests representing the actual column behaviour normally expressed in terms of a load-settlement relationship. Although, the disadvantages of this method include the relatively long time required and high costs undertake in performing such tests. "Moreover, it would not be feasible to perform pile load tests in the stage of project planning stage. "They are often conducted during the construction phase on production piles which cannot be loaded to failure" [18].

\subsection{Quick Pile Load Test}

\section{Evaluation of the Jet Grout Load-Settlement Results Based to Interpretation Methods}

To compare the total settlement results of the pile load test for jet grouting soil-cement column four selected interpretation methods was chosen to examine their accuracy for the calculate total settlement. In general, no specific method or criteria that can clearly describe the exact ultimate load or total settlement. However, these method including settlement requirements, mathematical and graphical methods for calculations [20].

\subsubsection{Modified Chin - Kondner Method}

Chin-Kondner method based on mathematical limitations, the method concluded that each movement in the pile load test results divided by the load and the resulting value is then drawn and represented with movement, after that the results falls as a straight line and the inverse of the slope is $1 / \mathrm{C} 1$ equals the ultimate bearing capacity of piles. In fact, the ultimate capacity represented by $\mathrm{Qu} / 1.2$ in this modified.

\subsubsection{Brinch Hansen's 90\% Method (1963)}

This method is based on trial and error and on the settlement limitations. This method has represented the relationship between load and movement, the ultimate bearing capacity is giving the twice movement of the pile head as represented by $90 \%$ of the ultimate bearing capacity.

\subsubsection{Butler and Hoy's Method (1977)}

The failure load of the pile is defined as the load at the intersection of a line tangent to the initial straight line portion of the load-settlement curve intersection with a line tangent to the load-settlement curve where the slope of the line reaches 0.05 inches/ton. This method is applicable for the quick pile load test.

\subsubsection{Fuller and Hoy's Method (1970)}

This method is based on the settlement limitations. The failure load of the pile is defined as the load at the intersection of the tangent of the load - settlement sloping off at 0.05 inches/ton with tangent parallel elastic line. This method is applicable for the quick pile load test. Therefore, the mathematical representation of settlement based on the ultimate load defined in interpretation methods as explain in Figure 12.
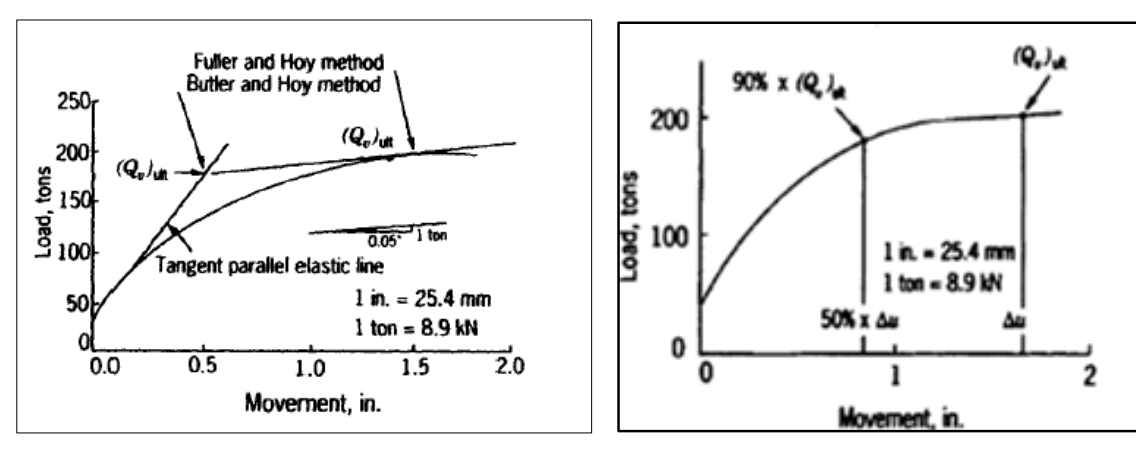

Hansen 90\% Method

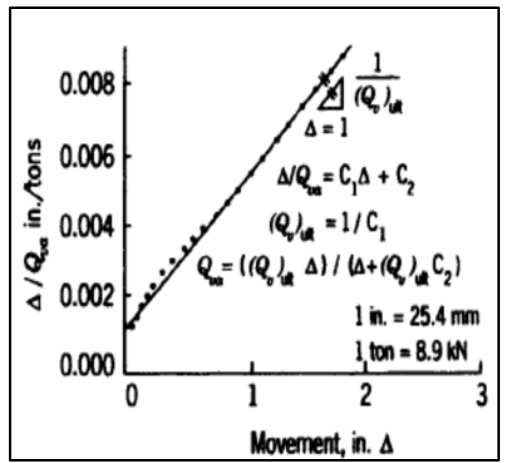

Chin-Kondner Method

Figure 12. Interpretation methods of pile load Test [20]

\subsection{Determination of Jet Column Load Bearing Capacity}

In performing pile load test, two settlement dial gauges were used to record the vertical settlement of the pile or soilcement column. The dial gauges were connected to the references beam. The arrangement of the load reaction was consist of a platform consist of iron H-beam section, the end of platform rested over timber gribbing and then over 
reaction support, the applied load on the head of pile consist of the load of platform and dead load of heavy material (a kentledge) were supplied by using a concrete blocks Figure 13. The static load - settlement curve can only be directly determined by a static in-situ test, which is then used to interpret the bearing capacity of piles ability to use one of the many methods of interpretation. However, due to several testing constraints, they cannot produce a "realistic" style of the load-settlement curve to the form that can be achieved by static testing.
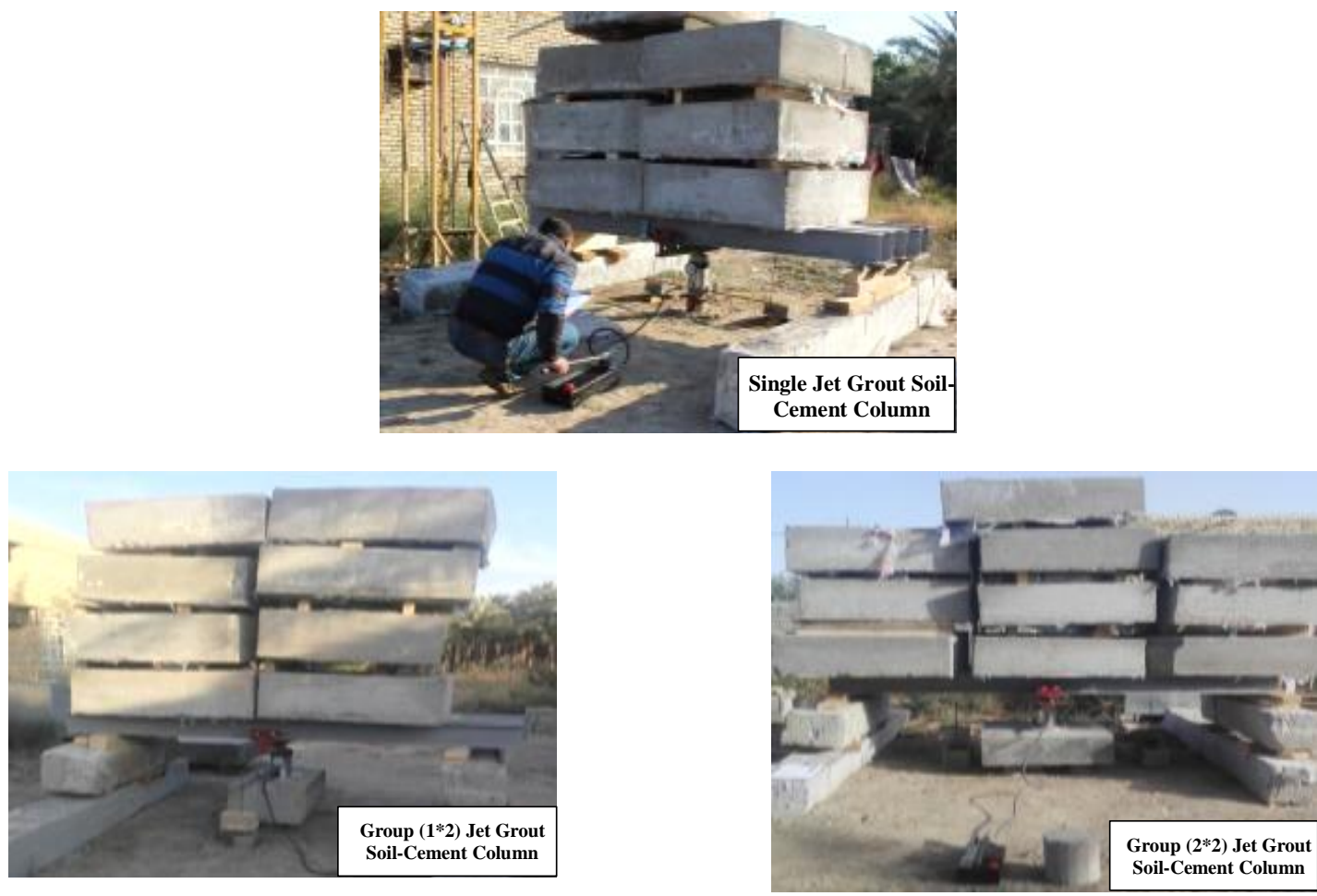

Figure 13. Pile load test for single, Group $(1 \times 2)$ and $(2 \times 2)$ jet grout soil-cement column

\subsection{Load-Settlement Test Results of Jet Grouting Soil-Cement Columns}

In foundation constructions, jet grout soil-cement columns are often considered as alternative pile to strengthen weak ground and move loads to surround, deeper and stronger layers. In a trial test to evaluate potential modifications induced on the soil by the jetting of columns, the axial loading tests are applied in to the columns. The subsequent results supported observation of full scale models of in situ check results of jet grouting soil-cement column. Several limits influenced the depth and diameter of jet grout soil-cement column like jetting pressure, radial rotation, and vertical motion of rod, the operation values and results will listed in Table 6 and illustrates in Figure 14.

Many interpretation theories have been proposed for estimation ultimate axial bearing capacity of jet grouted soil columns. The ultimate capacity for each casing of the jet grouting load settlements relationships corresponding total settlement are listed in Table 7. A comparison was made between measured ultimate load capacity of single and group jet grouting soil-cement column were listed in Table 8 .

Table 6. Parameters of construction the jet grouting soil cement-columns

\begin{tabular}{|c|c|c|c|c|c|c|c|}
\hline \multirow[b]{2}{*}{ Category } & \multicolumn{2}{|c|}{ Jet grout Dimensions } & \multirow{2}{*}{$\begin{array}{c}\text { Pile Group } \\
\text { Dimensions } \\
(\mathbf{m m})\end{array}$} & \multirow{2}{*}{$\begin{array}{c}\text { Water Jetting } \\
\text { Pressure } \\
\text { (Bar) }\end{array}$} & \multirow{2}{*}{$\begin{array}{c}\text { Grouting } \\
\text { Jetting Pressure } \\
\text { (Bar) }\end{array}$} & \multirow{2}{*}{$\begin{array}{l}\text { Rod Radial } \\
\text { Rotation } \\
\text { (rpm) }\end{array}$} & \multirow{2}{*}{$\begin{array}{c}\text { Rod Vertical } \\
\text { Motion } \\
(\mathrm{cm} / \mathrm{min})\end{array}$} \\
\hline & $\begin{array}{c}\text { Diameter } \\
(\mathbf{m m})\end{array}$ & $\begin{array}{c}\text { Length } \\
(\mathrm{mm})\end{array}$ & & & & & \\
\hline Single Jet Grout Column & 150 & 2000 & 150 & 75 & 6 & 40 & 30 \\
\hline Group $(2 \times 1)$ Jet Grout Column & 150 & 2000 & $500 \times 960$ & 75 & 6 & 40 & 30 \\
\hline Group $(2 \times 2)$ Jet Grout Column & 150 & 2000 & $960 \times 960$ & 75 & 6 & 40 & 30 \\
\hline
\end{tabular}


Table 7. Summary of Measured Ultimate Capacity of Jet Grout Column $(\mathrm{D}=150 \mathrm{~mm})$ from Pile Load Test

\begin{tabular}{|c|c|c|}
\hline \multicolumn{3}{|c|}{ Single Jet Grout Soil-Cement Column } \\
\hline Interpretation of Pile Load Test & Ultimate load Capacity $(\mathrm{kN})$ & Settlement (mm) \\
\hline Modified Chin -Kondner Method & 38.8 & ------- \\
\hline Hansen’s 90\% Method (1963) & 22.5 & 0.45 \\
\hline Butler and Hoy's Method (1977) & 21 & 0.47 \\
\hline Fuller and Hoy's Method (1970) & 16 & 0.32 \\
\hline \multicolumn{3}{|c|}{ Group of Jet Grout Soil-Cement Column $(1 \times 2)$} \\
\hline Interpretation of Pile Load Test & Ultimate load Capacity $(\mathbf{k N})$ & Settlement (mm) \\
\hline Modified Chin -Kondner Method & 86 & 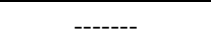 \\
\hline Hansen’s 90\% Method (1963) & 46.8 & 0.62 \\
\hline Butler and Hoy’s Method (1977) & 50 & 0.73 \\
\hline Fuller and Hoy's Method (1970) & 47 & 0.64 \\
\hline \multicolumn{3}{|c|}{ Group of Jet Grout Soil-Cement Column $(2 \times 2)$} \\
\hline Interpretation of Pile Load Test & Ultimate load Capacity (kN) & Settlement (mm) \\
\hline Modified Chin -Kondner Method & 143.4 & ------- \\
\hline Hansen's 90\% Method (1963) & 97.2 & 1.5 \\
\hline Butler and Hoy’s Method (1977) & 100 & 1.65 \\
\hline Fuller and Hoy's Method (1970) & 95 & 1.35 \\
\hline
\end{tabular}

Table 8. Comparison of Measured and Calculated Ultimate Bearing Capacity of Jet Grout Soil-Cement Column

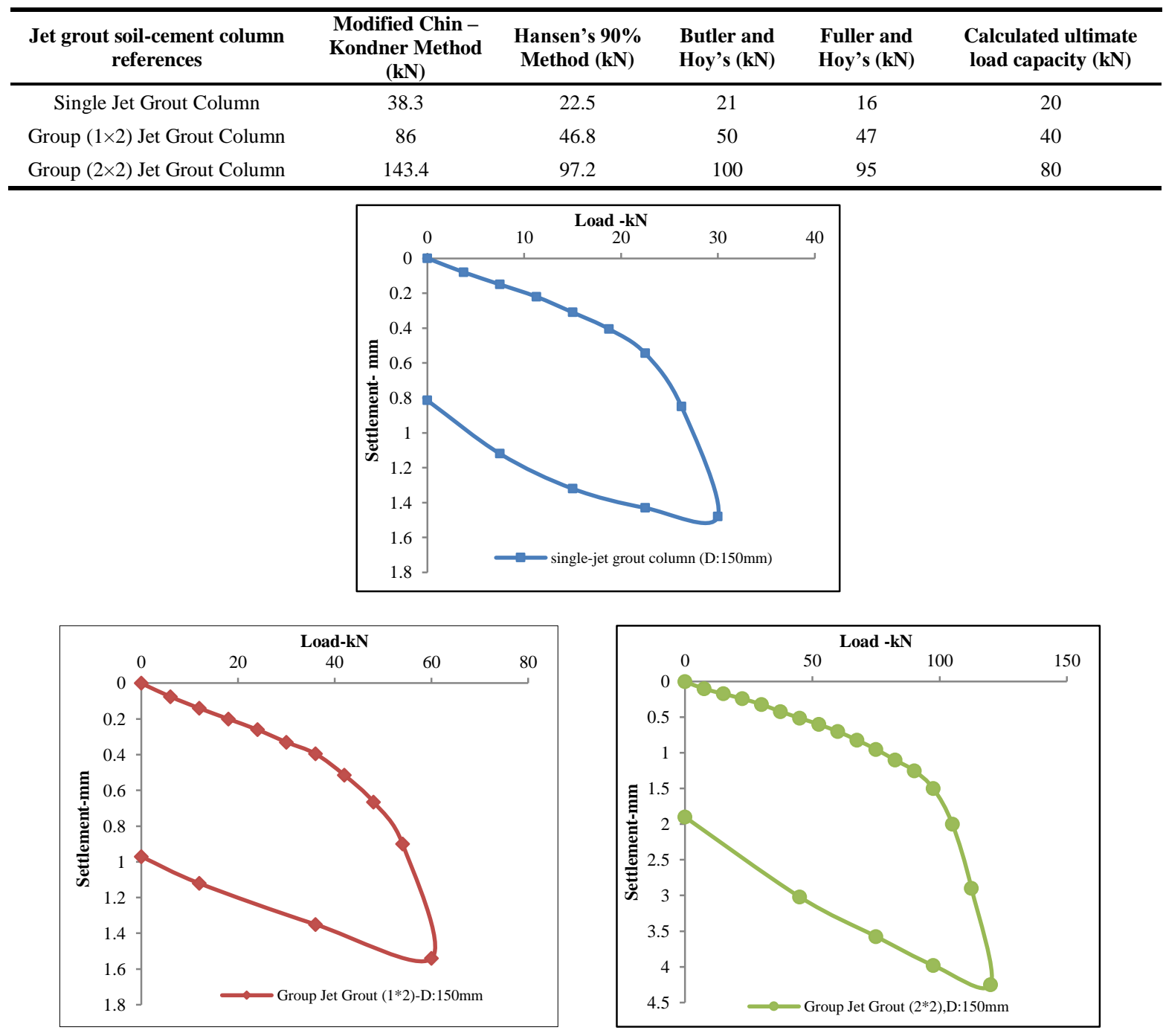

Figure 14. Load settlement curves of single and groups jet grout soil-cement column 
According to the load settlement test results of jet grouted column, the total head settlement and ultimate axial capacity for single and group were increases with increase a numbers of jet grout column in group, as shown in Figure 15.

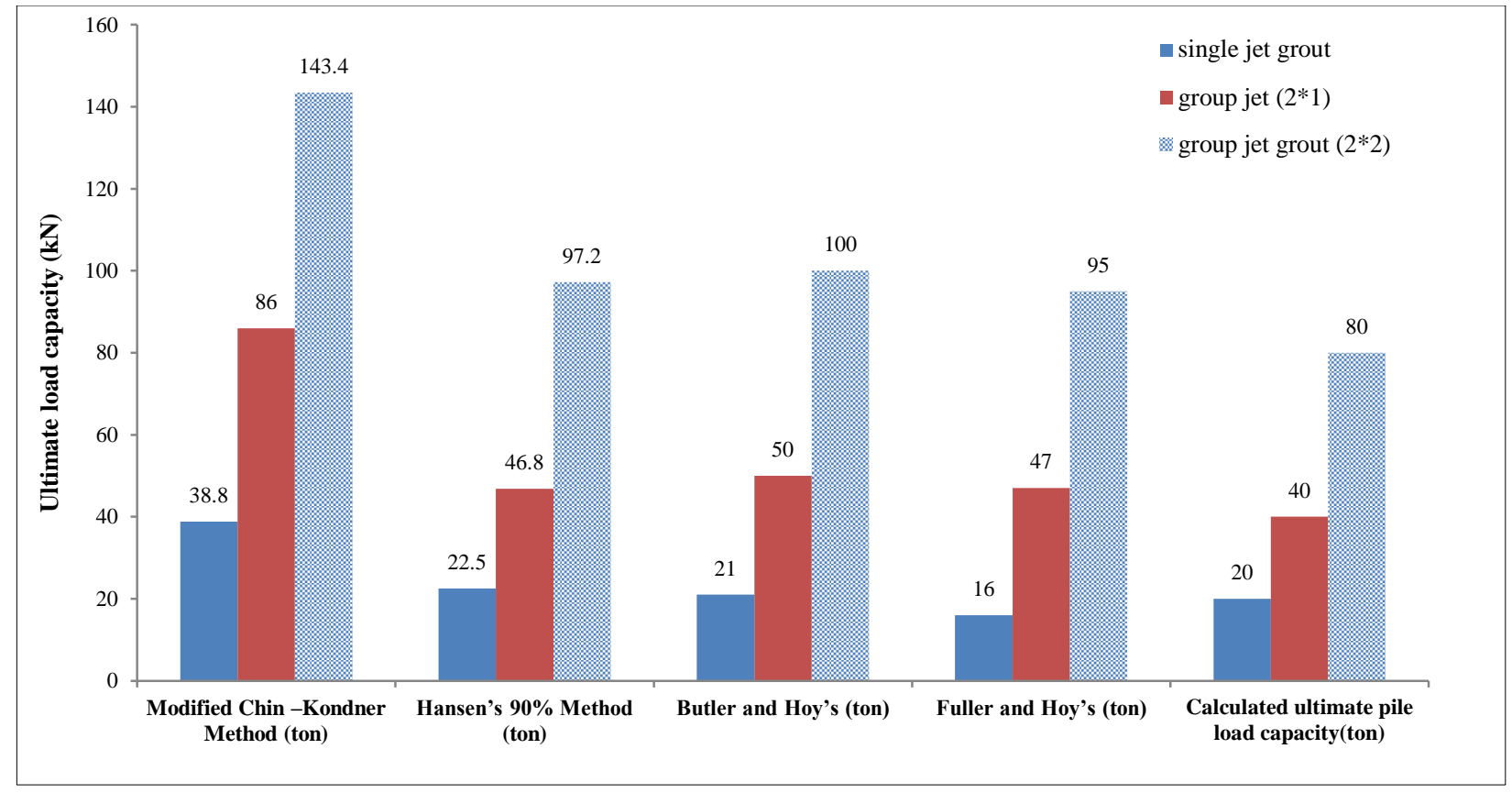

Figure 15. Comparison of measured and calculated ultimate bearing capacity jet grout soil-cement column

To comparison of interpreted ultimate axial load and measured load capacity, the ratio of interpreted ultimate to measured load (pu/pm), expressed in percent, were illustrated in histograms from Figures 16 to 18 for single and group jet grout soil - cement column.

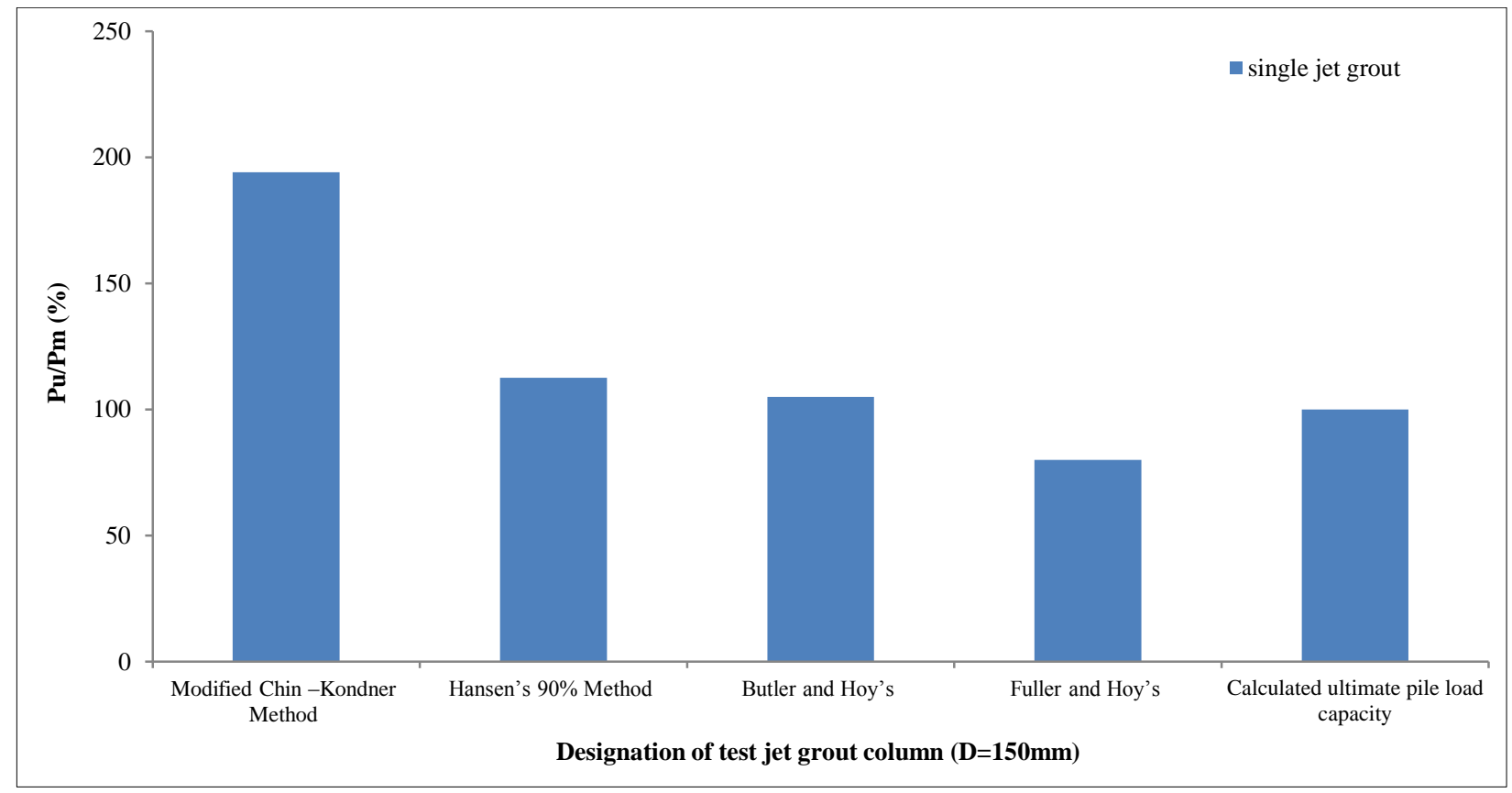

Figure 16. Percentage of $\mathrm{Pu} / \mathrm{Pm}$ for comparison interpreted ultimate and measured axial load capacity for single jet grout column 


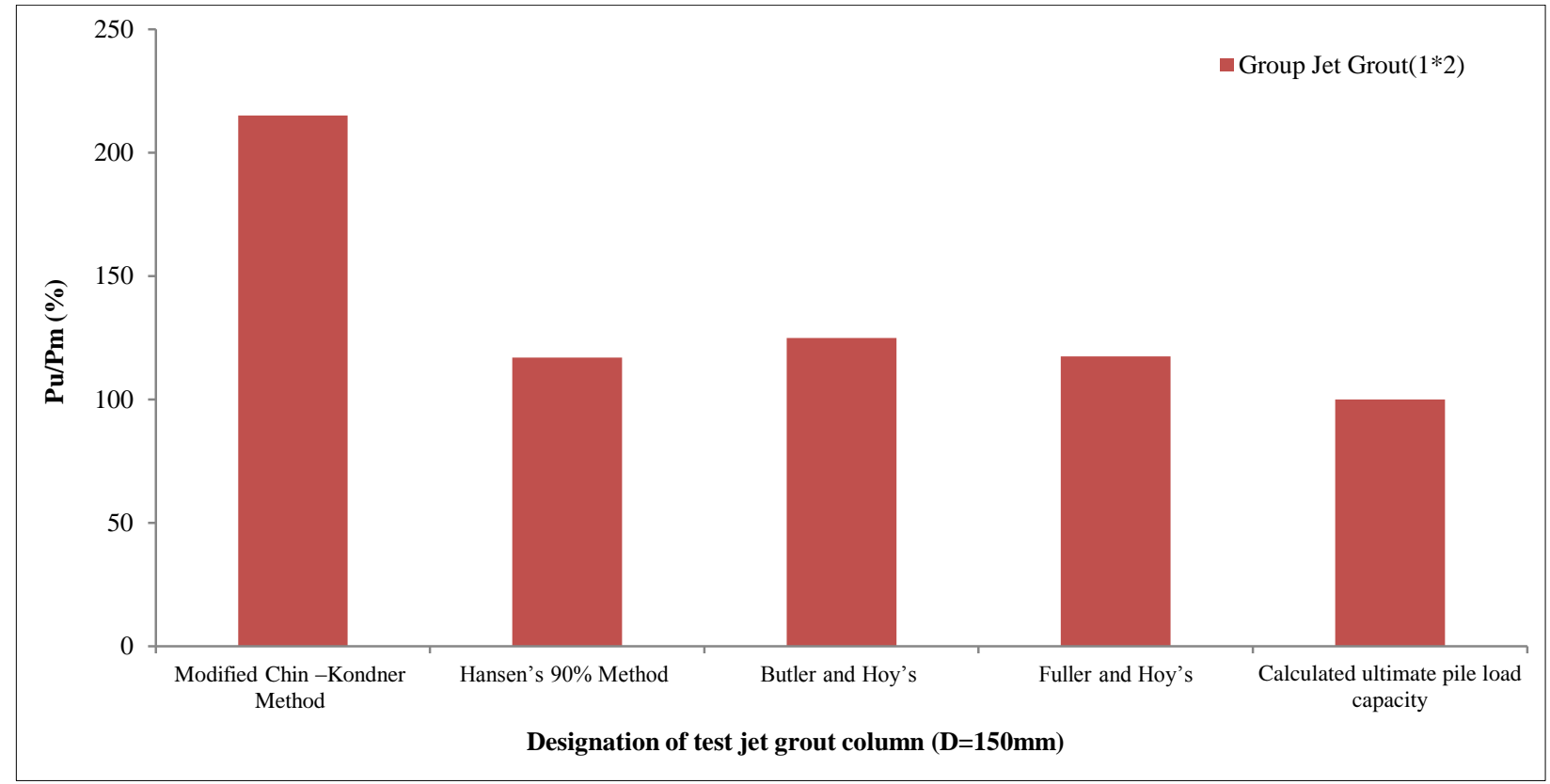

Figure 17. Percentage of $\mathrm{Pu} / \mathrm{Pm}$ for comparison interpreted ultimate and measured axial load capacity for group $(1 \times 2)$ jet grout column

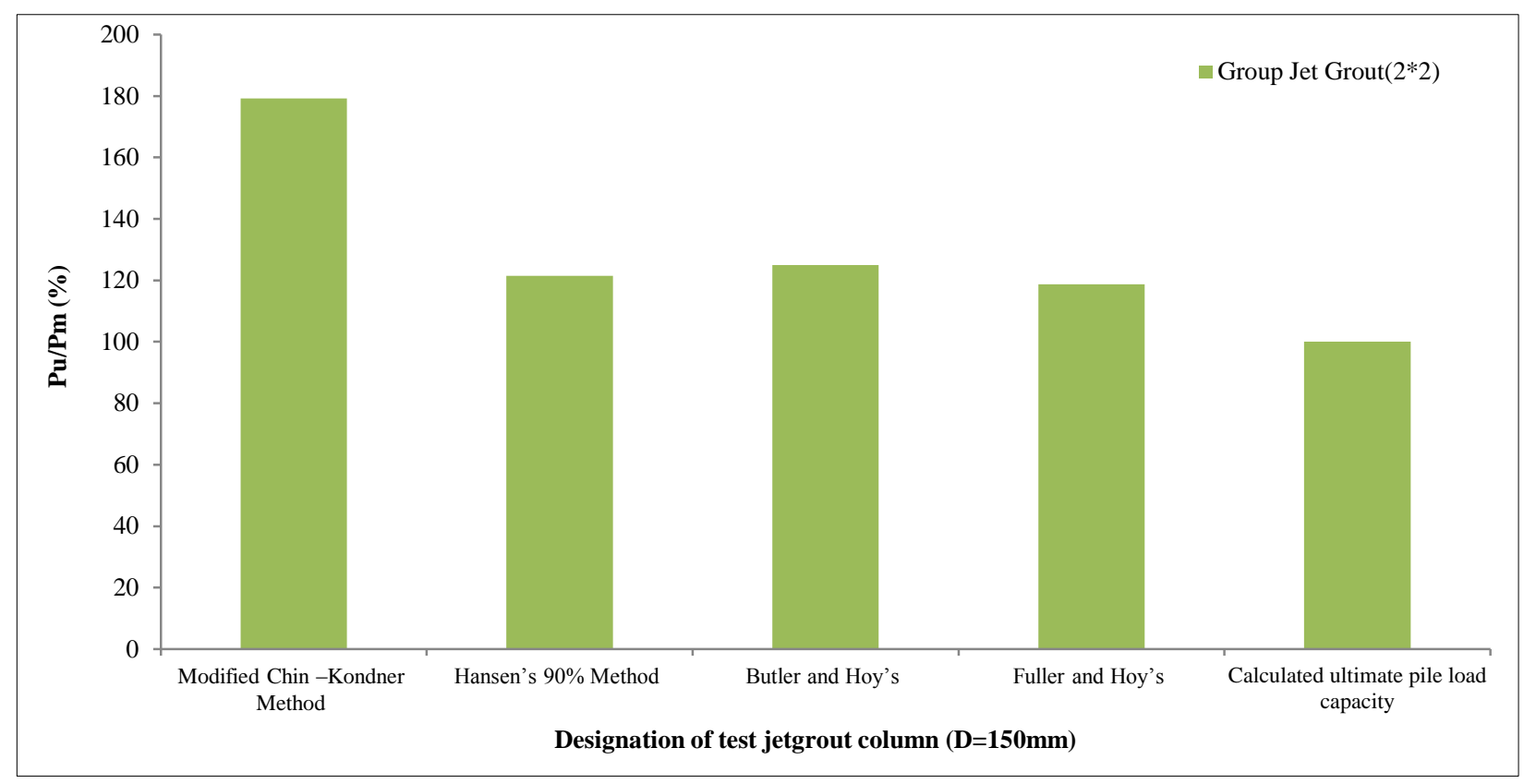

Figure 18. Percentage of Pu/Pm for comparison interpreted ultimate and measured axial load capacity for group $(2 \times 2)$ jet grout column

\section{Conclusions}

- Although the use of jet grouting at the last year is very common in foundation constructions. Therefore, an estimated design of soil-cement column is still based on simple ones assumptions that often come from accumulated deep foundations practice. Field work studies that can be characteristic of jet grout soil-cement column response to certain interact with the surrounding soil because of facility difficulties dimensions and mechanical properties of jet grout columns. According to the results obtained from the axial load-settlement and from the general comparison of ratios ( $\mathrm{Pu} / \mathrm{Pm})$, as illustrated above, the following can be stated:

- The total head settlement and ultimate axial capacity for single and group were increases with increase a numbers of jet grout column in group.

- The average Pu/Pm ratio varied considerably from $80 \%$ to $194 \%$ for single jet grout, while in group jet grout $(1 \times 2)$ varied from $117 \%$ to $215 \%$ and in $(2 \times 2)$ jet pile group was $119 \%$ to 179 . 
- Axial load capacity of jet grout estimation by Butler and Hoy's Method given closer value to measure value for single jet grouting about 105\%, while Modified Chin -Kondner Method given overestimated value (194\%).

- Axial load capacity of jet grout estimation by Hansen's 90\% Method and Fuller and Hoy's given closer value to measure value for group $(2 \times 1)$ jet grouting about $117 \%$, while Modified Chin -Kondner Method given overestimated value $(215 \%)$.

- Axial load capacity of jet grout estimation by Fuller and Hoy's Method given closer value to measure value for group ( $2 \times 2$ ) jet grouting about 119\%, while Modified Chin - Kondner Method given overestimated value $(179 \%)$.

- In general, from the results of the comparison of $\mathrm{P}_{\mathrm{u}}$ and $\mathrm{P}_{\mathrm{m}}$, it can be stated that the modified Chin-Kondner method gives an increase and over estimation in axial load values for all cases (single and group), while the Fuller and Hoy methods tend to underestimate the carrying capacity of a single jet grout around (80\%).

\section{Conflicts of Interest}

The authors declare no conflict of interest.

\section{References}

[1] Niermann, Matthew J., Douglas R. Jenevein, and Stanley L. Worst. "Jet Grouting for Water Cutoff and Excavation Support." Grouting 2017 (July 6, 2017). doi:10.1061/9780784480809.013.

[2] Pinto, Alexandre, Rui Tomásio, and Gonçalo Marques. "Ground Improvement with Jet Grouting Solutions at the New Cruise Terminal in Lisbon, Portugal.” Procedia Engineering 143 (2016): 1495-1502. doi:10.1016/j.proeng.2016.06.176.

[3] Abramson, Lee W., Joe C. Drumheller, and Kevan D. Sharp. "Ground improvement, ground reinforcement, ground treatment: developments 1987-1997." New York, NY: American Society of Civil Engineers, 1997.

[4] Pinto, Alexandre, Rui Tomásio, and Gonçalo Marques. "Ground Improvement with Jet Grouting Solutions at the New Cruise Terminal in Lisbon, Portugal.” Procedia Engineering 143 (2016): 1495-1502. doi:10.1016/j.proeng.2016.06.176.

[5] Karahan, Gulsah Nur, and Osman Sivrikaya. "Designing Singular Jet Grouting Column for Sandy Soils." Environmental Earth Sciences 77, no. 12 (June 2018). doi:10.1007/s12665-018-7650-9.

[6] Tran-Nguyen, Hoang-Hung, and Chuong Hong Quach. "Mechanical Behaviors of Soilcrete Created from Soils of Tam Bang and Vam Dinh Bridges Simulating Jet Grouting Technology.” Grouting 2017 (July 6, 2017). doi:10.1061/9780784480809.007.

[7] Chen, Jin-Jian, Lianyang Zhang, Jun-Feng Zhang, Yan-Fei Zhu, and Jian-Hua Wang. "Field Tests, Modification, and Application of Deep Soil Mixing Method in Soft Clay.” Journal of Geotechnical and Geoenvironmental Engineering 139, no. 1 (January 2013): 24-34. doi:10.1061/(asce)gt.1943-5606.0000746.

[8] Horpibulsuk, Suksun, Worawit Phojan, Apichat Suddeepong, Avirut Chinkulkijniwat, and Martin D. Liu. "Strength Development in Blended Cement Admixed Saline Clay.” Applied Clay Science 55 (January 2012): 44-52. doi:10.1016/j.clay.2011.10.003.

[9] Shen, Shui-Long, Zhi-Feng Wang, Suksun Horpibulsuk, and Yong-Hyun Kim. "Jet Grouting with a Newly Developed Technology: The Twin-Jet Method.” Engineering Geology 152, no. 1 (January 2013): 87-95. doi:10.1016/j.enggeo.2012.10.018.

[10] Bustamante M. 2002; Jet grouting columns. Report of the Seminar: Pathology of soils and foundations, Hammamet (Tunisia).

[11] Makovetskiy, O.A. "Application of 'Jet Grouting' for Installation of Substructures of Estates." Procedia Engineering 150 (2016): 2228-2231. doi:10.1016/j.proeng.2016.07.269.

[12] Malinin, Alexey, Ilya Gladkov, and Dmitriy Malinin. "Experimental Research of Jet-Grouting Parameters in Different Soil Conditions." Deep and Underground Excavations (May 14, 2010). doi:10.1061/41107(380)7.

[13] Juzwa, Anna, and Joanna Bzówka. "Numerical Simulations of Settlement of Jet Grouting Columns." Transactions of the VŠB Technical University of Ostrava, Civil Engineering Series. 16, no. 1 (March 1, 2016): 1-6. doi:10.1515/tvsb-2016-0001.

[14] Fan, Jianguo, Dongyuan Wang, and Duo Qian. "Soil-Cement Mixture Properties and Design Considerations for Reinforced Excavation." Journal of Rock Mechanics and Geotechnical Engineering 10, no. 4 (August 2018): 791-797. doi:10.1016/j.jrmge.2018.03.004.

[15] Bzówka, Joanna, Anna Juzwa, Konrad Wanik, Lidia Wanik, and Tomasz Żyrek. "Discussion on the Influence of Various Technological Parameters on Jet Grouting Columns Geometry." Transactions of the VŠB - Technical University of Ostrava, Civil Engineering Series. 15, no. 1 (June 1, 2015): 11-16. doi:10.1515/tvsb-2015-0002.

[16] ACI Committee 318. (2014). Building Code Requirements for Structural Concrete (ACI 318-14): An ACI Standard: Commentary on Building Code Requirements for Structural Concrete (ACI 318R-14): an ACI Report. American Concrete Institute.

[17] Poulos, Harry George; DAVIS, Edward Hughesdon. Pile foundation analysis and design. 1980. 
[18] Zein, A. K. M., \& Ayoub, E. M. (2016). Evaluation of measured and interpreted failure loads of bored piles in alluvial soil deposits. International journal of GEOMATE: geotechnique, construction materials and environment, 10(1), 1636-1643.

[19] ASTM, D 1143/D 1143M - 07, "Standard Test Methods for Deep Foundations under Static Axial Compressive Load".

[20] Shamsher Prakash and Hari D. Sharma, 1990, "Pile Foundations In Engineering Practice", Copyright at 1990 by John Wiley \& Sons, Inc. 